\title{
Work-Life Balance Among Employees in the Workplace and Covid-19: An Empirical Perspective
}

\author{
Lilian Ifeoma Akunne* Juliana Akuezilo $(\mathrm{PhD}) \quad$ Vera Nwadinobi $(\mathrm{PhD}) \quad$ Anulika Valantina Etele $(\mathrm{PhD})$ \\ Department of Guidance and Counselling, Nnamdi Azikiwe University, PO box 5025, \\ Awka Anambra State, Nigeria
}

\begin{abstract}
The objective of this study is to examine work life balance among employees in the workplace and COVID-19. The study adopted the descriptive survey research design. Three research questions guided the study. The population and sample were drawn form Anambra and Enugu states. The accessible population of this study comprised of 4768 employees (business administrators, contractors, lecturers) in Anambra and Enugu states, Nigeria. The sample of the study is 992 employees in the workplace, that is, business administrators, contractors, lecturers drawn using proportionate stratified sampling technique. The instrument for data collection is a questionnaire structured on a 4-point Likert scale. The data collected were analysed using mean and standard deviation. The findings of the study revealed that employees in the workplace strongly agreed to the indices of work life balance among employees in the workplace, they agreed to the challenges and the possible solutions of work life balance among employees in the workplace and COVID-19. It was concluded that most of these indices, challenges and solutions are triggered by the Nigeria unique workplace, culture and institutional framework that impact managing work life balance. On the other hand, given that the support of Nigerian government and non-government organizations is possibly in short supply, studies need to be carried out to further investigate this phenomenon for enhanced work life balance among employees in workplace in Nigeria.
\end{abstract}

Keywords: Work-life, workplace, employees, coronavirus (COVID-19), pandemic

DOI: $10.7176 /$ RHSS/11-24-04

Publication date: December $31^{\text {st }} 2021$

\section{Introduction}

Coronavirus (COVID-19) is currently ravaging the countries of the world including Nigeria. COVID-19 is traced to Hunan Seafood Market of Wuhan city in the Hubei Province of China as declared by China CDC and Chinese Health Authority (Gralinski \& Manachery, 2020). Yu Han (2020) While WHO first declared SARS-COV-2 as a Public Health Emergency of International Concern (PHEIC) on January 30, 2020. SARS-COV-2 (coronavirus disease) fondly called by many people as China disease was officially renamed COVID-19 on 11th February 2020. Transmission of the novel virus COVID-19 is human to human though said to have started from animals and can be direct in transmission from respiratory droplets produced by an infected person while coughing or sneezing or indirect transmission by touching a surface or object that has the virus on it and then touching their own mouth, nose, and eyes (Novel Coronavirus Pneumonia Emergency Response Epidemology Team, 2020). SARS-COV-2 (COVID-19) has a unique pathogenicity and transmissibility, which has been confirmed to be highly infectious than SARS-COV and MERS-COV. An encounter with COVID-19 patient can easily lead to cross infection from one person to another in absence of personal protective equipment for example: Masks, gown, goggles, boots, gloves. SARS-COV-2 has a powerful infectivity as it binds to angiotensin-converting enzyme 2 (ACE-2) receptors in the afflicted patient thereby, showing a higher affinity than SARS-COV-S (NCPEREPT, 2020).

However, the recent out-burst of COVID-19 pandemic seems to be affecting workers of all walks of life. In order to save lives, social distancing procedures have been extreme but necessary, helping to control the spread of the virus and flatten the high rising curve. Despite such trying times, the altruistic nature of the human population has been revealed in a wave of solidarity across the planet. However, it is becoming clear that social distancing measures will increase social inequity amongst workers if not properly addressed during and after the COVID-19 crisis. More so, as a result of the pandemic, humans have all suddenly faced significant changes in both homes and the workplace. Unfortunately, those who tend to feel the impact of the pandemic surge are the low paid workers who do not have access to employment protection and other incentives (Frasquiiho, Matos, \& Salonna, 2016). They further stated that, as workers are just beginning to adapt to the new working condition, they are faced with a large degree of uncertainty about the future. In addition to the health impacts of virus itself, a negative impact on their overall health is foreseen due to the effect of quarantine and the economic recession.

The evolution from perceiving work life balance practices merely as a process of accepting different personnel with various tasks to identifying their role towards administrative effectiveness is a significant paradigm swing that is still much on course. Employees play a key role in any business formation and therefore there is need to provide an enabling environment at all levels, so as to attain the stated objectives and goals of the organization. However, demand between work and home is becoming a major concern for employees in recent 
years. Some of this anxiety has to do with the demographic and workplace changes, especially for women in the labour force that are required to do longer working hours (Azeem \& Akhtar, 2014). In reaction to these alterations alongside the dispute they produce between the numerous roles that individual hold, various establishments are gradually pressured to come up with work practices arrangement that will facilitate employee's efforts to accomplish both their work related and their private errands (Ryan \& Koseek in Abioro, Oladejo, \& Ashogbon, 2018). Work life balance is a critical issue which is of paramount worry to every employee at different level be it public or private segment alike. The issue is far more than prioritizing the work role and one's personal life. It equally has a way of influencing ones psychological, social, economic and ultimately the mental well-being of an individual. Nevertheless, the above assertion will reflect in the output of the employees, which invariably affect his or her productivity at workplace in the long run if not properly managed (Ojo, Salau \& Falola, 2014). Fundamentally, work life balance practices are essential part of human resource management which is getting collective and adequate consideration from government, employers of labour and researchers. Reason being that, it is a solid component of motivation for improved organizational responsiveness with respect to application and administration of balance of work life strategies. It is also related with stability in-between the quality of time and energy an individual dedicates to work and private undertakings in order to sustain a harmonious life. The practice of work life balance approaches are to enhance stability between the hassles of the occupation and the robust management of life outside work station and flexible work environment.

Consequently, concerns are being raised about the acute and long-term effects on employees in the workplace. Employee's productivity in any organization is a key area in the work environment. It assists the business to develop the capability of the human resources in the system to be competent. Productivity means the end result of an activity of a person or organization. According to Chris and Awonusi in Abioro, Oladejo and Ashogbon (2018), confirmed productivity as a process of measuring and scrutinizing the responsibilities of employees in the organization. Therefore, an organization required an increase level of productivity of its employee's in order for the stated goals to be achieved. Different empirical research conducted have been in support to the fact that an individual will contribute to the development of their organizations when they enjoy a work life balance (Oswald, 2012). This revealed that the success of any organization largely rests on the productivity of employees within the system. It is therefore, necessary for managers at the helm of business affairs to adopt the approach that will lead to employee's retention. The essence of balancing both private and work life is to encourage healthy environment that can guarantee loyalty of the staff and secure high level of productivity. Consequently, the combination of flexibility of work schedule together with job attitude has been linked to increase in organizational commitment from employees, satisfaction from the job and most especially reduction in turnover intention (Lewis \& Gambles in Abioro, Oladejo, \& Ashogbon, 2018).

According to Adisa, Mordi and Osabutey (2017), attempts have been made that globally to research on work life balance in a pre and post COVID era, however, it is still at an incipient stage in developing countries, such as Nigeria, which is understudied. Thus, countries in Africa constitute a populace with a neglected and little understood area of inquiry, this situation constitutes a research gap given disparities in institutional system likely to affect work life balance and careers (Ituma, Simpson, Ovadje, Cornelius, \& Mordi, 2011). Consequently, the main concern of this study is to fill the pre-existing lacuna by specifically exploring work-life balance among employees in the workplace and covid-19. In this wise, researchers have called for what Ituma et al. (2011) referred to as country-specific career studies in Africa and other non-western nations so as to widen perspectives about the issue of work life balance among employees in the workplace and the COVID-19 pandemic. This empirical approach has the tendency to guide the development of career management theory and practice in several regions of the world including Nigeria. Furthermore, given Nigeria's increasing economic significance in the world economy, an exploration of how work life balance realities manifest as well as impinge on social sustainability is vital for better understanding of its unique workplace context, institutional frameworks that shape employment and global sustainability issue (Chandra, 2012). With some remarkable exceptions, literature on work life balance in western countries of the world reflects a correlation between organizational effectiveness, performance, productivity among others. Buttressing further, in spite of scholars and researchers' efforts in the management field to look into the frequent challenges being faced by worker's job and their personal life, employees still experience conflict as regard the job and individual life as they continue to look for the kind of life they desired. Hence, harmonizing work and family life poses as a major challenge facing employees in the organizations. Nevertheless, the circumstances surrounding employees in the workplace in reference with their work life balance and COVID-19 has not been empirically established, hence the focus of this study.

\subsection{Purpose of the Study}

The purpose of this study is to determine work life balance among employees in the workplace and COVID-19. Specifically, the study will determine;

- Indices of work life balance among employees in the workplace and COVID-19. 
- Challenges of work life balance among employees in the workplace and COVID-19.

- Solutions to the challenges of work life balance among employees in the workplace and COVID-19.

\subsection{Research Questions}

- What are the indices of work life balance among employees in the workplace and COVID-19?

- What are the challenges of work life balance among employees in the workplace and COVID-19?

- What are the solutions to the challenges of work life balance among employees in the workplace and COVID-19?

\section{Review of Related Literature}

\subsection{Work life balance}

Compared to occasional mode of working operations under normal circumstances, carrying out work duties during the COVID-19 pandemic is far more challenging because it is mandatory, rather than voluntary, and fulltime, rather than part-time or occasional. Surveys conducted with people working from home during the pandemic reveal that there are also positive experiences with working from home (Cartmill, 2020). The most useful tool to support workers with maintaining their work-life balance is to manage work load by results and not by focusing on the number of hours or the particular schedules that they work. By keeping the workload manageable and setting clear, realistic expectations regarding the specific results to be achieved, workers are better equipped to organize their own time and tasks, in order to effectively balance their work obligations with their personal lives, including their family responsibilities.

One of the most significant challenges employees are facing during the pandemic is the work-life conflict they are experiencing due to blurred boundaries between work and personal life. Blurring of the boundary between paid work-personal life is always an issue with certain employment (employees), even in the best of times, but it seems to be particularly problematic due to the unique circumstances of the pandemic. Indeed, the COVID-19 crisis has shattered the notion that paid work and personal life are two entirely separate domains, as well as the ideal worker myth that workers can and should always be available to perform their work-related functions. Studies have shown that health related activities increase work intensity and work-home interference, leading to adverse effects on the well-being and stress-levels of employees (Eurofound, COVID-19 could permanently change teleworking in Europe , 2020).

People with children find the combination of school and child care facility closures with prolonged, fulltime work particularly challenging. In a recent survey, over one in five persons (22 per cent) living with young children (under 12) reported difficulties in concentrating on their job all or most of the time, compared to just 5 per cent of households with no children and 7 per cent with children aged 12-17 (Eurofound, 2020). Specifically, single parents or parents of children with a disability or learning difficulty report that the situation is very stressful. On the other hand, survey respondents reported that they appreciated the absence of time and stress of commuting to the office; spending more time with their children and spouses, and the flexibility of the working hours. But how can workers effectively disconnect from work when their personal and working lives have become so blurred together? The following actions among others may be considered by organizations to help improve the work-life balance of their teleworking employees, including by enabling them to effectively disconnect from work during specified periods:

- Supporting work-life boundary management by setting clear expectations about work outputs, and at the same time offering workers the flexibility to manage their own work schedules based on their individual needs.

- Ensuring that workers feel empowered to disconnect from work at specified times reserved for rest and personal life without negative repercussions for their careers.

- Encouraging open communication and cooperation between workers and managers around scheduling, availability, and boundary-setting within teams.

- Supporting workers with small children or other care responsibilities who may be facing difficulties getting their work done and living up to the expectations of their employers. Such individuals should be supported with targeted measures, such as the special parental leave schemes that have been put in place in several countries, organized on the basis of social dialogue and consultations between workers and employers, on either a full-time or part-time basis.

\subsection{Understanding work life balance}

The concept of work life balance though contemporary, defines a notion that is rather old (Chandra, 2012). As scholars have suggested, there is no precise definition of work life balance. Furthermore, Clark (2000) noted that work life balance is about satisfaction and good functioning at work and at home, with a minimum of role conflict. More so, work life balance is the extent to which an individual is equally engaged in and equally 
satisfied with their work role and family role. That it is widely assumed to be a matter of choice which individuals including employees are free to make. However, the study of work life balance across many countries which indicates that there are always paradoxes about this choice (Karatepe, 2010) as well as finding equilibrium in balancing work and the social in which the demands of everyday life impinge on work life balance. Operationally, work life balance represents the interface of work and family and the consequences of these two variables on commitment to work, job satisfaction, family roles and social related themes such as work growth.

\subsection{The Nigerian context}

Nigeria is a constitutional republic in West Africa. It is the most populous country in Africa with over 182 million people (National Population Commission of Nigeria, NPCN, 2019). It is also the largest economy in Africa (Watts, 2016). Given Nigeria's population, natural and human endowments, it is often referred to as the giant of Africa y all Nations of the world. However, the country's political leadership, work environment and muffled trade unionism have caused most professionals, in particular medical professionals, to migrate to other countries with better prospects (Human Resource for Healtha and Fact Sheet, HRHFS, 2010). Issues of poor working condition of doctors are associated with work life balance challenges beset Nigeria's health sector (Ovuorie, 2013). For instance, it is reported that over 8, 893 medical doctors migrated from Nigeria to countries such as the UK, the USA, South Africa, Germany, Ireland, Poland and the West Indies, among others in search of a greener pasture (HRHFS, 2010). The health sector is made up of private and public/government hospitals. It is regulated by the Medical and Dental Council of Nigeria (MDCN). As reported by Human Resources for Health Fact Sheet, Nigeria has the biggest base of health workers in Africa (HRHFS, 2010) with around 55, 375 medical doctors that practice in different areas on the country. This scenario makes Nigeria an interesting and unique context to explore specifically regarding work life balance.

The health sector as well as other sectors of economic activities presents an area that needs illumination for work life balance challenges and their attendant social issue. Additionally, nearly four decades ago, Nigeria's health sector was deemed to be understaffed, it was reported that around 500 doctors were available for over one million Nigerians. Given the intensity of migration, only about 600 paediatricians are left to treat and care for the country's 40 million population of children in contrast to the UK that has well over 5, 000 paediatricians for 20 million children. Similarly, Ovuorie (2013) stated that this situation triggers strike and industrial disputes. The shortage of doctors in Nigeria is perhaps responsible for high mortality rate in the country that stands at 73 deaths against 1,000 births. Also, shortage of doctor's accounts for work life balance demand and pressure on Nigerian (female) doctors; there is thus a correlation between this and doctors' workload, hours of working and work life balance challenges.

In spite of the attraction of work life balance practice as a subject of academic discussion, and the amount of popularity of schedule practices (i.e. a supportive-family-friendly-policy) in organization across the globe, study on the productivity level of employees of such strategy is not that incorporated (Leblebici, 2012). An assessment of the previous work, however, question the supposed connection between work life balance and employee productivity. The research in respect to work life which reflects the stability between workplace and people's personal life has been evaluated over time. According to Clarke in (Abioro, Oladejo, \& Ashogbon, work life balance practices and employees' productivity in the Nigerian University system, 2018) work life balance reflects on fulfilment level of the worker in operating excellently both at work and home respectively. Essentially, there are different perspectives to the concept of work life balance. From the employee's standpoint, it is the protection of one's family alongside with the responsibilities at work. However, employer's viewpoint as regard the advantage, is in connection with all other fringe benefits attached to the working conditions of their employees.

While previous work life balance study centers on workers family duties, there are studies that identify the commitment to associates and communal groups, expanding the affected population to virtually all employees (Abioro, et al. 2018). According to Hill, Hawkins, Ferris and Weitzman (2010), flexitime help workers to be in control of their family and work responsibilities which permit them to improve the level of productivity at work and also reduction in work family conflict at home. A research by Meyer and Kirsten in Abioro, et al. (2018) on nursing mothers working in the best 100 companies in the world, discovered that organization that subscribe to work life balance programs enjoyed better revenue rates. However, a survey conducted by European institute on employee's condition of work, confirmed that $85 \%$ of people that work below 30 hours per week were pleased with their work life balance. Rau (2003) carried out an assessment in the health sector in Kenya of a nongovernmental group which endorse the implementation of excellence WLB practices.

In a related study by Abioro (2017), it was learnt that a deficient flexible schedules' inconsistent friendlyfamily strategy, do have a negative impact on workers which most often reduce job performance and some leading to broken homes. Consequently, a similar study shows that one key source of stress that is significant, according to $69 \%$ of staff interviewed is workload; while the remaining $41 \%$ are of the opinion that they 
typically feel tense or strained out during workday (Oludayo, Gberevbie, \& Popoola, 2015). It is therefore imperative to say that an individual with great level of social and physical state of mind are likely to perform well in an organization compare with employees suffering from emotional security. Moving from perception to reality, there are number of studies that has a contrary view to the concept of work life balance practice. However, after studying the literature on work life balance practices on employee's productivity, it revealed that such programs do not certainly lower the levels of employees work life conflict. An employee may think that using work life programs set up by the organization may affect his/her career progression in the system as well as the perception of management of not being committed to the development of the business. Therefore, this study intends to contribute to this ongoing discussion by examining empirically work-life balance among employees in the workplace and COVID-19: An empirical perspective.

\section{Method}

The study adopted the descriptive survey research design. According to Nworgu, (2015) descriptive survey is aimed at collecting data on and describing in a systematic manner the characteristics, features or facts about a given population. Nworgu (2015) further affirmed that studies that adopt such design are interested in describing certain variables in relation to the population. Hence, descriptive survey research design is considered appropriate for this study because the study seeks examine work life balance among employees in the workplace and COVID-19. This survey was carried out among employees in selected workplaces in Anambra and Enugu states. The population of this study comprised of 4768 employees in private establishment in Anambra and Enugu states, Nigeria. The sample of the study is 992 employees. This sample was drawn using proportionate stratified sampling technique, this was done by first stratifying the respondents in terms of occupation type (business administrators, contractors, lecturers). Based on this stratification, 400 business administrators, 220 contractors and 372 lecturers. The instrument for data collection is a questionnaire structured on a 4-point Likert scale of Strongly agree - 4, Agree - 3, Disagree - 2, Strongly disagree - 1 respectively. The questionnaire was administered using the direct delivery approach, in this approach, the respondents where approached in their respective offices and establishments as well as institutions. Respondents who could complete the instrument on the spot did so and the instruments were retrieved immediately. Nevertheless, questionnaires of respondents who could not complete them on the spot where retrieved after one week of administration. The data collected was analysed using mean and standard deviation. Specifically, the standard deviation was used to determine the homogeneity and heterogeneity of the respondent response.

\section{Results and Discussion}

The results and discussion of this study are presented as follows;

4.1 Research Question 1: What are the indices of work life balance among employees in the workplace and COVID-19?

Table 1: Mean and standard deviation on the indices of work life balance among employees in the workplace and COVID-19 (N=992)

\begin{tabular}{|l|l|l|l|l|}
\hline S/N & Items statement & Mean & SD & Decision \\
\hline 1 & Reduction of working hours & 2.41 & 1.01 & Agree \\
\hline 2 & Increase in negativity during official hours & 2.76 & .78 & Agree \\
\hline 3 & Family life and home activities & 3.41 & .92 & Strongly agree \\
\hline 4 & Employees in the Workplace locus of control & 2.01 & .83 & Agree \\
\hline 5 & Lack of deprivation owed to unemployment & 3.63 & .86 & Strongly agree \\
\hline 6 & Company benefits among employees in the workplace & 3.42 & .92 & Strongly agree \\
\hline 7 & In-house child care & 3.11 & 1.02 & Strongly agree \\
\hline 8 & Productive work among employees in the workplace & 3.15 & 1.00 & Strongly agree \\
\hline 9 & Appreciation among employees in the workplace & 3.40 & .65 & Strongly agree \\
\hline 10 & Flexible working hours and work model (home office) & 3.33 & .74 & Strongly agree \\
\hline & Grand Mean & $\mathbf{3 . 0 6}$ & & Strongly Agree \\
\hline
\end{tabular}

Data presented in table 1 shows the mean and standard deviation rating of employees on the indices of work life balance among employees in workplace and COVID-19. From the result above, the respondents strongly agreed with 7 items and agreed to 3 items. On the whole, the grand mean of 3.06 shows that the respondents strongly agreed to the indices of work life balance among employees in the workplace and COVID-19. On the other hand, the standard deviation shows heterogeneity of the respondent's response $(1.02-0.65)$.

The findings of this study revealed that employees in the workplace strongly agreed to the indices of work life balance in the workplace. This aligns with the findings of Frasquiiho, Matos and Salonna (2016) who found that those who tend to fill the impact of the pandemic surge are the low paid workers who do not have access to employment protection and other incentives. This goes to imply that one of the indices of work life balance 
among employees in the workplace is imbalance among employees. In a similar note, Mushfiqur, Oruh, Nwabgara, Mordi and Turner (nd) supports this study as they found that factors such as work pressure, cultural expectations, unsupportive relationships, challenging work environment, gender role challenges, lack of voice/participation and high stress level moderate the ability of female medical doctors to manage work-life balance and social sustainability. It also identifies that socio-cultural and institutional demands on women show that these challenges while common to female physicians in other countries, are different and more intense in Nigeria because of its unique professional, socio-cultural and institutional frameworks.

4.2 Research Question 2: What are the challenges of work life balance among employees in the workplace and COVID-19?

Table 2: Mean and standard deviation on the challenges of work life balance among employees in the workplace and COVID-19 (N=992)

\begin{tabular}{|l|l|l|l|l|}
\hline $\mathbf{S} / \mathbf{N}$ & Items statement & Mean & SD & Decision \\
\hline 1 & Unrealistic demands among employees in the workplace & 2.01 & .92 & Agree \\
\hline 2 & Lack of control among employees in the workplace & 3.12 & .69 & Strongly agree \\
\hline 3 & Unsupportive relationships among employees in the workplace & 1.11 & .78 & $\begin{array}{l}\text { Strongly } \\
\text { disagree }\end{array}$ \\
\hline 4 & Lack of resources to meet demand of employees in the workplace & 2.09 & .65 & Agree \\
\hline 5 & Unhelpful attitude among employees in the workplace & 2.74 & .61 & Agree \\
\hline 6 & Lack of pre-requisite skills among employees in the workplace & 2.43 & .87 & Agree \\
\hline 7 & High-stress levels among employees in the workplace & 2.56 & .81 & Agree \\
\hline 8 & Mistaking business for productivity & 1.01 & .82 & $\begin{array}{l}\text { Strongly } \\
\text { disagree }\end{array}$ \\
\hline 9 & Being a perfectionist during office activities & 2.31 & .77 & Agree \\
\hline 10 & $\begin{array}{l}\text { Reacting to everything immediately within and outside the working } \\
\text { environment }\end{array}$ & 1.24 & .92 & $\begin{array}{l}\text { Strongly } \\
\text { disagree }\end{array}$ \\
\hline & Grand mean & $\mathbf{2 . 0 6}$ & Agree \\
\hline
\end{tabular}

Data presented in table 2 shows the mean and standard deviation rating of employees in the workplace on the challenges of work life balance among employees in the workplace and COVID-19. From the result above, the respondents strongly agreed with 1 item, agreed with 6 items, and strongly disagreed to 3 items. On the whole, the grand mean of 2.06 shows that the respondents agreed to the challenges of work life balance among employees in the workplace and COVID-19. On the other hand, the standard deviation shows heterogeneity of the respondent's response $(1.12-0.61)$.

On the other hand, the findings further revealed that the respondents agreed to the challenges of work life balance among employees in the workplace and COVID-19. This findings agree to the study of Chandra (2012) which found that given Nigeria's increasing economic significance in the world economy, an exploration of how work life balance realities manifest as well as impinge on social sustainability is vital for better understanding of its unique workplace context, institutional frameworks that shape employment and global sustainability issues.

4.3 Research Question 3: What are the solutions to the challenges of work life balance among employees in the workplace and COVID-19?

Table 3: Mean and standard deviation on the solutions to the challenges of work life balance among employees in the workplace and COVID-19 ( $\mathrm{N}=992)$

\begin{tabular}{|l|l|l|l|l|}
\hline S/N & Items statement & Mean & SD & Decision \\
\hline 1 & Setting boundaries and working hours & 3.76 & .67 & Strongly agree \\
\hline 2 & Accepting that there is no perfect work life balance & 2.47 & .74 & Agree \\
\hline 3 & Finding a job that is loved & 3.11 & .81 & Strongly agree \\
\hline 4 & Prioritizing your health, and giving it greater attention & 4.00 & .91 & Strongly agree \\
\hline 5 & Making time for yourself and loved ones & 2.78 & .86 & Agree \\
\hline 6 & Setting goals and priorities and sticking to them & 3.10 & 1.01 & Strongly agree \\
\hline 7 & Knowing the available options in the work place & 3.00 & .96 & Agree \\
\hline 8 & Staying in the forefront of duties & 3.65 & .95 & Strongly agree \\
\hline 9 & Providing means of telecommunication among health workers & 1.21 & 1.01 & $\begin{array}{l}\text { Strongly } \\
\text { disagree }\end{array}$ \\
\hline 10 & $\begin{array}{l}\text { Retaining employers as part time or contractors, or using phased } \\
\text { retirement }\end{array}$ & 2.37 & .67 & Agree \\
\hline & Grand mean & $\mathbf{2 . 9 4}$ & & Agree \\
\hline
\end{tabular}

Data presented in table 3 shows the mean and standard deviation rating of work life balance of employees 
in the workplace on the solutions to the challenges of work life balance among employees in the workplace and COVID-19. From the result above, the respondents strongly agreed with 5 items, agreed with 4 items, and strongly disagreed to 3 items. On the whole, the grand mean of 2.94 shows that the respondents agreed to the possible solutions to the challenges of work life balance among employees in the workplace and COVID-19. On the other hand, the standard deviation shows homogeneity of the respondent's response $(.67-1.01)$.

More so, it was further revealed through the findings of this study that the respondents agreed to the possible solutions to the challenges of work life balance among employees in the workplace and COVID-19. Through this, employees in the workplace will likely strike a balance between work life and other future endeavours during the post COVID-19 era. This finding aligns with Nkeruwen, Ejinaka, Obeta, Adebowale and Udoudoh (2020) who found that they should be continuous construction of State by State laboratory network for easy access and quality medical laboratory testing (diagnosis) for all. Similarly, more employees in the workplace with good insurance/payment packages to ensure optimal performance should be recruited. More so, decentralize testing of COVID-19 and possibly use regional centres as confirmation where the states cannot confirm.

\section{Conclusion}

Conclusively, this study examined work life balance among employees in the workplace and COVID-19. This empirical study was conducted with specific objectives such as the indices of work life balance among employees in the workplace and COVID-19, challenges of work life balance among employees in the workplace and COVID-19, solutions to the challenges of work life balance among employees in the workplace and COVID-19. As observed, most of these indices, challenges and solutions are triggered by the Nigeria unique workplace, culture and institutional framework that impact managing work life balance. On the other hand, given that the support of Nigerian government and non-government organisations is possibly in short supply, studies need to be carried out to further investigate this phenomenon for enhanced work life balance among employees in the workplace in Nigeria. These studies with empirical findings will aid in reconfiguring Human Resource, HR policies and work practices that will be beneficial to both employees and employers in Nigeria. These will further widen research using the lens of institutional theory, recognize cross-national disparities and advocate the call for development of positive working environment, context-bound theories and realities implicated in HR policies and people management.

\section{References}

Abioro, M. A. (2017). Assessment of employee's job recognition as a panacea for business survival in Nigeria: A pilot study. Uniosun international journal of business administration, 1(1), 154-162.

Abioro, M. A., Oladejo, D. A., \& Ashogbon, F. O. (2018). work life balance pracices and employees productivity in the Nigerian University system. Crawford Journal of business and Social sciences, 12(2), 49-59.

Adisa, T. A., Mordi, C., \& Osabutey, E. (2017). Exploring the implications of the influence of organizational culture on work life balance practices: Evidence from Nigeria medical doctors. Personnal Review, 46 (3), 454-473.

Cartmill, C. (2020). New survey shows 87\% of staff wish to work from home in post lcokdown world. Belfest: Belfest News Letter, 28.

Chandra, V. (2012). Work life balance: Eastern and western perpective. International Journal of Human Resource Management,23(6), 100-113.

Eurofound. (2020). COVID-19 could permanently change teleworking in Europe. Dublin: Eurofound, 26th March.

Eurofound. (2020). Living, working and COVID-19: First findings-April 2020. Dublin: Eurofound.

Frasquiiho, D., Matos, M. G., \& Salonna, F. (2016). Mental health outcomes in times of economic recession: A systematic literature review. BMC: Public health.

Gralinski, I., \& Manachery, V. D. (2020). Return of the coronavirus. 2019-nCov, Virus 12, 135.

Hill, E., Hawkins, A., Ferris, P., \& Weitzman, M. (2010). Finding an extra day a week: The positive influence of perceived job flexibility on work and family life balance. . Journal of business management, 50(1), 49-58.

Human Resource for Healtha and Fact Sheet, HRHFS. (2010). Country profile Nigeria: AFrican Health Observation Workforce. www.unfpa.org/sowmy/docs/library/R050AHWO2008 NigeriaHRHProfile.pdf. (Accessed 25/05/2017).

Ituma, A., Simpson, R., Ovadje, F., Cornelius, N., \& Mordi, C. (2011). Four domains of career success: How managers in Nigeria evaluate career outcomes . International Journal of Human Resource Management, 22(17), 978-995.

Karatepe, O. M. (2010). the effect of positive and negative work-family interaction on exhustion. . International Journal of Hospitality Management, 22(6), 836-856. 
Leblebici, D. (2012). Impact of workplace quality on employees productivity: Case study of a Bank in Turkey. Journal of Business Economics, 1(1), , 65-78.

Mushfiqur, R., Oruh, E. S., Nwabgara, U., Mordi, T., \& Turner, I. (nd). The Impacts of Work-Life-Balance (WLB) Challenges on Social Sustainability: The Experience of Nigerian Female Medical Doctors. 1-25.

Nkeruwen, S. E., Ejinaka, R. O., Obeta, M. U., Adebowale, O. M., \& Udoudoh, M. P. (2020). Coronavirus (COVID-19): Review from a Nigerian perpective . Africn Journal of Biomedical Science and Researc, 9(1), 26-34.

Novel Coronavirus Pneumonia Emergency Response Epidemology Team. (2020). The epidemology chracteristics of an outbreak of 2019 novel corona virus diseases (COVID-19) in China. Zhonghua Liu Xing Bing Xue Za Zhi 41: , 145-151.

Nworgu, B. G. (2015). Educational research: Basic issues and metodology (3rd Ed.). Enugu: University Trust Publishers.

Oludayo, O., Gberevbie, D. E., \& Popoola, D. (2015). A study of multiple work-life balance initiatives in banking industry in Nigeria. International Research Journal of Finance and Economics, 13(3), , 108-112.

Ovuorie, T. (2013). Nigerian health sector faces critical doctor shortages. Acessed on 24th September 2020: available at:http:// premiumtimesng.com/news/143393-investigation-1-nigerias-health-sector-facescriticaldoctorshortages.html.

Yu Han, H. Y. (2020). the transmission and diagnosis of 2019 novel coronavirus infection disaese (COVID-19): A chinese perspective. Journal of Medical Virlogy. 